\title{
REVIEW
}

\section{Marine ecological research in seashore and seafloor systems: accomplishments and future directions}

\author{
James A. Estes ${ }^{1, *}$, Charles H. Peterson ${ }^{2}$ \\ ${ }^{1}$ U.S. Geological Survey, Biological Resources Division, A-316 Earth and Marine Sciences Building, University of California, \\ Santa Crux, California 95064, USA \\ ${ }^{2}$ Institute of Marine Sciences, University of North Carolina at Chapel Hill, Morehead City, North Carolina 28557, USA
}

\begin{abstract}
Research in seashore and seafloor communities has contributed immensely to the conceptual growth of ecology. Here we summarize some of the most important findings and discuss needs and opportunities for future work. Disproportionately large numbers of the most influential contributions are derived from studies of rocky shores and coral reefs because aspects of these systems (accessibility) and of their most common species (sessile or weakly motile, high density, short generation time) make them well suited to manipulative experiments. Foremost among the research contributions from seashore and seafloor systems are increased understanding of (1) competition and consumer-prey interactions, (2) trophic cascades and other indirect species interactions, (3) the evolution of defense and resistance in consumer-prey systems, (4) the importance of propagule transport and recruitment variation to adult populations, (5) the impacts of physical disturbance, and (6) the generation and maintenance of species diversity on ecological time scales. We acknowledge the importance of manipulative experiments in the growth of marine ecology, but question whether a strict adherence to this approach will best serve future needs. Some of the most pressing needs for future knowledge are: (1) documenting the complex influences of spatial and temporal scales on ecological processes, (2) identifying the role of large, mobile predators in marine ecosystems, (3) understanding factors limiting marine autotrophs, (4) integrating historical biology and neontology, and (5) appreciating intersystem linkages. Increased attention to conducting arrays of experiments, taking measurements and observations, and documenting change at larger scales of space and time will provide insights that are unattainable by the commonly used methodological protocols. Novel approaches, including (1) evaluating and managing human disturbance for the joint purpose of conservation and learning, (2) developing stronger ties between scientists working in open-ocean and near-shore systems, and (3) developing collaborative projects among scientists in the academic, governmental, and private sectors are required to understand many of these processes.
\end{abstract}

KEY WORDS: Coral reefs Ecological concepts - Kelp forests - Novel approaches - Rocky shores . Unconsolidated substrates

\section{INTRODUCTION}

The broad goal of ecological research is to understand the structure and dynamics of populations, com-

•E-mail: jestes@cats.ucsc.edu munities, and ecosystems. Marine and estuarine systems associated with the seafloor, especially on coastal hard substrata, have contributed substantially to this agenda. Here we review important conceptual advances that are based on research in seashore and seafloor systems, the system-level characteristics and research approaches that have led to these contributions, the 
resulting strengths and limitations of current knowledge, and visions of what is both possible and necessary to move the field toward interesting and useful new horizons. Our focus is on spatial patterns and temporal dynamics of populations and communities, the processes that explain them, and the level of success that science can achieve in understanding and predicting those patterns and dynamics. This is not a comprehensive, in-depth review, but rather an overview, strongly influenced by our own experiences and perspectives. Despite our potentially non-representative viewpoints, however, the ideas expressed in this review have been exposed to and modified by extensive input from dozens of our colleagues in the field of ocean ecology.

Marine ecological systems associated with the seafloor occur from near the poles to the equator and from the intertidal zone to the deepest ocean bottom; thus, they are necessarily characterized by immense taxonomic and physical/chemical variation. This variation can be categorized in numerous ways. We divide it in the traditional fashion by substrate type - hard versus unconsolidated (soft) - -because this is a recurrent and reasonably dichotomous distinction among marine benthic systems, and the methods used and many of the processes investigated segregate accordingly. Most work on population, community and ecosystem dynamics has come from studies in nearshore and estuarine environments, and our presentation is weighted accordingly.

\section{STATE OF THE FIELD}

\section{Hard-substrate systems}

Hard-substrate systems are common from the intertidal zone to the deep sea, and notably include intertidal rocky headlands, boulders, and limestone benches (Connell 1972, Sousa 1979, Underwood \& Denley 1984), shallow subtidal rock walls (Witman 1987) and reefs (Connell et al. 1997), seamounts (Genin et al. 1986, 1989, Keating et al. 1987), and hydrothermal vents, where rocky crust is being actively formed (Grassle 1986, Tunnicliffe 1991). Our focus is mainly on shallow-water systems-rocky shores, coral reefs, and kelp forests. All 3 systems have been productive arenas for ecological research because they are comparatively easy to access and observe; many of the key organisms are abundant, sessile or weakly motile, and have short generation times; and some strong interactions among species tend to characterize specific systems (Paine 1980, Menge et al. 1994). This is not to say that all species are strong interactors (most may not be), but rather that at least some strong interactors have been found virtually everywhere scientists have looked for them in these habitats. The suite of characteristics of these hard-substrate systems in shallow water makes manipulative experiments both feasible and profitable, an approach that has come to dominate ecological research in hard-substrate systems in recent decades (Dayton \& Oliver 1980, Paine 1994, Rafaelli \& Hawkins 1996). Experimental manipulation is far more limited in the deep sea, but the development of manned and unmanned research submersibles has created new opportunity for exploring ecological dynamics in these systems (e.g. Thistle \& Levin 1998).

A list of contributions from research in hard-substrate marine systems would be vast. One need only peruse titles from the general ecological and marine specialty journals to see this. Several recurrent themes emerge from the profusion of research. A substantial proportion of papers addresses pair-wise interactions among species or guilds of species. Most of them focus on competition (Connell 1983) or consumer-prey interactions (Schmitt 1987). Definitive evidence for the importance of both processes is provided by studies of numerous taxa in many areas of the world. A second theme concerns the indirect effects of apex consumers on lower trophic levels (Power et al. 1996). Indirect effects of apex predators typically play out in 1 of 3 ways - via trophic cascades, in which top consumers facilitate autotrophs by limiting populations of midlevel consumers (Fretwell 1987, Carpenter \& Kitchell 1993); via preferential consumption of competitive dominants, which frees limiting resources and enhances diversity among competitors (Paine 1966, Connell 1978); or via positive species interactions including, especially, provision of biogenic habitat by 'bioengineers' (Jones et al. 1994). Studies built around the second of these processes provide important evidence for the Intermediate Disturbance Model of species diversity (Connell 1978, Lubchenco 1978, Sousa 1979). A third theme to emerge from research on coastal marine systems concerns the ecological and evolutionary roles of defense and resistance in consumer-prey interactions (Hay \& Fenical 1988). Although there is empirical evidence of defense and resistance for a variety of trophic levels, geographic regions, and modalities of defense, the most well-developed findings concern the role of secondary plant metabolites in plant-herbivore interactions within tropical/subtropical reef systems. A final theme of conceptual importance is 'supply-side ecology' - the notion that dispersive life history stages (usually spores and larvae) significantly influence the population dynamics of adult stages in species with complex life cycles (Sale 1977, Doherty \& Williams 1988, Roughgarden et al. 1988, Underwood \& Fairweather 1989, Caley et al. 1996). Larval characteristics and physical transport processes are also important in explaining the rapid colonization of habitat patches in 
dynamically open systems, such as newly created hydrothermal vents (Mullineaux et al. 1995).

\section{Soft-substrate systems}

Unconsolidated sediments characterize the sea floor over a large fraction of the global ocean. Habitats range from intertidal sandy beaches and protected estuarine mudflats to deep-sea deposits. Physical regime and water depth, which in turn influence sediment disturbance and grain size, play dominant roles in establishing community composition and character in marine soft sediments (Hall 1994).

Study of the dynamics of soft-sediment populations and communities has an almost century-long history, dating from early Scandinavian pioneers. Some of the initial focus of this work addressed questions of the relationships between benthic invertebrate-prey resources and demersal fishes in the North Sea (Blegvad 1928). In the mid 20th century, other Scandinavian marine ecologists made important advances in relating reproductive modes and larval life histories to dispersal and recolonization dynamics of benthic invertebrates (Thorson 1950, Segerstrale 1962). Modern rescarch has stressed experimental approaches in evaluating the roles of physical and biological disturbance in organizing soft-sediment systems (Woodin 1976, Elmuren et al. 1986, Hall 1994). By integrating fluid dynamics and sedimentology with ecology, much progress has been made in understanding recruitment dynamics of softsediment invertebrates (Eckman 1983, Nowell \& Jumars 1984, Butman 1987, Olafsson et al. 1994). Interdisciplinary research also has characterized the significant historical focus on habitat relationships in soft-bottom environments (Snelgrove \& Butman 1994).

Listing the major contributions of soft-sediment investigations to our general understanding of the dynamics of natural systems is necessarily idiosyncratic. Nevertheless, many people would include the following facets. (1) The study of soft-sediment benthic communities as a function of water depth has revealed the maintenance of extremely high species diversity at great depths, with diversity increasing with global area of habitat despite the low rates of energy provision (Grassle 1989). Although the mechanisms responsible for these depth-related patterns are still in question, this work has produced many conceptual contributions to theories of biodiversity maintenance (Rex et al. 1993, Pineda \& Caswell 1998). Research on evolution and maintenance of coral diversity has had similarly large impacts on understanding biodiversity (Connell 1978, Hughes 1989, Jackson 1991, Karlson \& Cornell 1998). (2) Predation by crustaceans and fishes has been shown to reduce density of soft-sediment invertebrates in many shallow habitats that lack such structural barriers to foraging as aquatic vegetation or shell debris (Peterson 1979, Oliver \& Slattery 1985, Olafsson et al. 1994, but see Rafaelli \& Hall 1992). (3) Important demonstrations of tri-trophic interactions have emerged from estuarine experiments, showing that fish, wading bird, and shorebird predation is often directed preferentially towards predatory crustaceans, large predatory polychaetes, or small demersal fishes, thereby releasing population controls on their smaller invertebrate prey (Kneib \& Stiven 1982, Commito \& Ambrose 1985, Wilson 1986, Kneib 1988). (4) The strong interactions significant to soft-sediment community dynamics do not generally include interspecific competition, but instead involve either predation and physical disturbance of the sediments or transformation of the physical habitat by creating an emergent or seabed structural habitat (Nowell \& Jumars 1984, Peterson 1991, Hall 1994). (5) Food limitation is generally important to both main functional groups of basal consumers ir soft sediments-deposit and suspension feeders (Levinton \& Lopez 1977. Peterson \& Black 1987). Seasonal food availability contributes on a large scale to temporal dynamics by inducing pulses of reproductive activity and settlement, but on local scales it is growth rate not abundance that responds most commonly to competition for food in this system (Wildish \& Kristmanson 1997)

\section{DEVELOPMENT OF INNOVATION}

Ecologists may differ greatly in their personal lists of the most interesting conceptual developments in understanding the dynamics of benthic/demersal marine ecosystems. Regardless of one's perspective, it is easy tc embrace the view that marine ecology has long been and continues to be a productive area of scientific research, and thus that external guidance, infrastructhral changes, and imposition of new visions represent unnecessary interference with a successful formula. Under this philosophy, an effective strategy for funding agencies might be simply to let science proceed in the future as it has in the past, banking on the expectation that continued productivity by a renewable resource of imaginative scientists will provide the substrate for intellectual growth through individual and collaborative creativity and original syntheses of accumulating knowledge. A critic of this philosophy, on the other hand, could reasonably make the following argument: while history clearly indicates past successes (as briefly discussed above) and staying the course promises even more in the future, the very methods that have led to these successes and the conceptual themes that have emerged from them con- 
dition our thinking, constrain our creativity, and inhibit our capacity for innovation. We believe that there is truth in both perspectives, that these views are not mutually exclusive, and that an effective agenda for research should thus contain elements of each philosophy. Our major motivation for writing this paper is to address issues that emerge under the latter view and thereby encourage marine ecologists to consider honestly and thoughtfully how they may break through constraints of vision that they may not even recognize exist. What, then, would we like to know about seashore and seafloor systems and what opportunities exist for facilitating the novel research needed to obtain that knowledge?

\section{Critical gaps in understanding}

This section identifies important issues that are still poorly understood. With each, we discuss opportunities for catalyzing novel and recent developments in technology that offer hope of progress.

Scale. This is an older issue (Dayton \& Tegner 1984, Levin 1992), although it is as topical and elusive now as ever before. Some of the questions pertaining to scale are: (1) Over which dimensions of space and time do the most significant organizing processes operate? (2) Can measurements to understand these processes be scaled accordingly, or must they be? and (3) What are the patterns of generality and variation within and across processes and ecosystems? These important questions have led to considerable debate. Their relevance to ecology also transcends coastal and seafloor marine ecosystems. We see several opportunities for increased understanding of questions of scale and, as in the past, work on benthic/demersal marine systems could play a leading role. One such opportunity is the use of metaanalyses to evaluate patterns across multiple studies (Gurevitch \& Hedges 1999). An emerging scientific culture of ecological synthesis needs to be cultivated and supported. The rich informational base from past research in benthic/demersal systems seems ripe for such an approach, and recent examples are exciting and encouraging (Menge et al. 1994, Caley et al. 1996). A second opportunity is conducting experimental studies on varying spatial and temporal scales (Thrush et al. $1997 \mathrm{a}, \mathrm{b})$. This has always been possible, but is rarely done. Long-term data sets, sometimes even utilizing historical, archaeological or paleontological information, have provided novel temporal perspectives on marine systems (Simenstad et al. 1978, White 1987, Allen \& Smith 1988, Dayton 1989, Baumgartner et al. 1992, Connell et al. 1997, Jackson 1997, Dayton et al. 1999). A third opportunity comprises the potential use of new technology in Geographic Information. System
(GIS) mapping and analysis and in satellite imagery to investigate ecological processes on larger spatial scales than was possible heretofore

Large, mobile predators. Understandably, ecologists have focused attention on those species they could most easily manipulate, i.e. small to moderately sized organisms that do not wander widely and are abundant in small areas amenable to experimentation. This selectively excludes certain groups of species from study, thus providing a potentially biased picture of important patterns and processes in benthic/demersal systems. Scientists have speculated about the ecological roles of such highly mobile groups as marine mammals, birds, and large fishes, but have not known how to incorporate them adequately into compelling evaluations. This problem is exacerbated by the fact that prevailing standards of scientific rigor (which emphasize experimental manipulation, replication, and local controls) that are often achievable in studies of relatively small-bodied, sessile or weakly mobile species (Paine 1994) are difficult or impossible to meet in addressing such questions for large, highly mobile components of the ecosystem. Furthermore, many scientists who study mobile marine vertebrates assume a strong bottom-up vicw of ecosystem dynamics, thereby creating a perspective of 'response to' rather than 'effect on' their environment as the domain of inquiry. New approaches-ranging from technological to conceptual to philosophical-are needed for research on these species. Natural history observations, usually obtained opportunistically, often are a source of significant insight into the ecological roles of these elusive creatures. Recent advances in the development of instruments for tracking and measuring the behavior and physiology of large, mobile marine vertebrates promise new insights into such questions as where and how they forage (Gentry \& Kooyman 1986 , Block et al. 1993, Davis et al. 1999). Further understanding of their roles in community organization and dynamics could be obtained in 4 ways: (1) excluding them from areas where they are otherwise abundant, (2) protecting them in areas where they are otherwise rare or have become rare due to exploitation, (3) tracking long-term changes in populations and communities in response to intentional management actions, and (4) using historical data from archaeology or paleontology to infer relationships between community structure and the presence-absence of large mobile predators. Using marine reserves for largescale experiments is a useful approach for studying some species. Because of the dramatic impacts of fishing, especially on seafloor communities in the coastal zone (Dayton et al. 1995), the use of reserves as an adaptive management experiment is especially promising (Lauck et al. 1998) 
Limiting factors on autotrophs. Plants have long commanded particular attention in ecological studies because of their pre-eminence in controlling the flux of energy and nutrients and because of their importance as 'ecosystem engineers' (sensu Jones et al. 1994) in providing or modifying structural habitat for other organisms. Four factors are thought to limit marine plant populations-physical disturbance, herbivory, light, and nutrients. While there is abundant evidence for each, a broad synthesis of their joint influence is lacking for 2 main reasons: first, past studies have tended to focus on single factors; second, methodological differences among different investigators have made geographic and taxonomic contrasts difficult to interpret. Both problems are technically resolvablethe first by conducting multi-factorial experiments and the second by establishing a programmatic infrastructure wherein similar approaches are used to study different areas and different species.

Historical biology. Ecologists working on marine benthic/demersal systems seem to have taken an unusually strong existential/neontological view of the world, thus endeavoring to understand the workings of marine systems from the perspective of extant species characteristics and community composition, with relatively little thought given to history that extends beyond individual memory. Important new insights can be obtained when ecologists expand their time scales to include evolutionary processes and historical events (Simenstad et al. 1978, Jackson 1991, Steinberg et al. 1995). This goal is best achieved by ecologists joining forces with biogeographers, historians, archaeologists and paleontologists. The knowledge of recent historical status of community composition and population abundance can help discriminate between climatic explanations for change such as climatic regime shifts (Anderson \& Piatt 1999) and human exploitation or habitat modification (Martin 1973). In addition, evaluation of longer histories of community composition provides insight into the evolutionary conditions and interactions that shaped the species that we study today. Use of molecular genetic techniques offers special promise in defining the geographical dimensions of populations and taxonomic relationships among species. This molecular approach wil] also help define the spatial structure of exploited populations, which is certain to improve management and clarify relationship between the openness of populations and diversity maintenance especially critical to understanding the deep sea (Powers et al 1990). More work at the interface of ecology and evolution promises exciting new discoveries (Palumbi 1992).

Linkages among ecosystems. Most prior research on marine benthic/demersal systems has proceeded by identifying or defining specific systems and attempting to understand organizational processes within each. One notable exception is 'supply-side ecology' (Gaines \& Roughgarden 1987, Roughgarden et al. 1988), wherein the oceanic realm is recognized as a potential transport vector for the dispersive life-history stages of otherwise sessile and weakly motile species. Presently, this is an area of active research in marine ecology. Similar interactions between the physical transport vectors such as internal waves and benthic organisms and communities have been responsible for remarkable new discoveries on subtidal rock walls (Witman et al. 1993) and coral reef environments (Leichter et al. 1996). Otherwise, the nature and importance of linkages among various marine and even terrestrial ecosystems are poorly known. Coastal benthic/demersa] systems are especially interesting in this regard because they are juxtaposed with the land on one side and the open sea on the other, and in both cases significant linkages between systems occur via physical (oceanic, atmospheric, riverine) and biological (mobile species) transport mechanisms (Polis et al. 1997, Paerl et al. 1998). New opportunities for the study of such processes are available with recent developments in isotopic analyses, remote sensing, satellite imagery, GIS technology, and instrumentation for tracking animals at sea

\section{OPPORTUNITIES AND CHALLENGES}

As is true for any successful endeavor, one challenge faced by benthic/demersal ecologists is to shed the constraints of tradition - not absolutely, for the value of small-scale manipulative experiments has not and may never run its course, but sufficiently to recognize other needs, to more freely explore opportunities, and perhaps even to rethink the standards of scientific inference. While admittedly something of a potpourri, we urge that programmatic infrastructures be implemented to emphasize or take advantage of the following issues

\section{Effects of human exploitation}

Human activities perturb natural ecosystems on scales than cannot be achieved for the purpose of learning alone. For instance, there is little doubt that fisheries have dramatically affected fish stocks and marine communities (Dayton et al. 1995, Botsford et al. 1997, Pauly et al. 1998). While most emphasis has been on simply documenting the effects of fishing on fishes, the fact that so many coastal fish stocks have been depleted provides numerous opportunities for understanding their ecological roles. Marine reserves, to the extent that they protect fish stocks from depletion and 
enhance their recovery, also should be looked to as important research opportunities (e.g. Alcala \& Russ 1990, Lauck et al. 1998).

\section{Long-term, large spatial-scale studies}

The vast majority of even the best research on marine benthic/demersal systems has been done over a period of just a few years at 1 or 2 sites. Benthic ecologists must expand their efforts to encompass longer and larger scales (Brown 1995). Some work of this nature has been done (e.g. Connell et al. 1997), mostly through the initiative of individual investigators rather than as a consequence of programmatic infrastructures. The few data available are sufficient to demonstrate that these approaches produce important insights not otherwise attainable (see Brown \& Heske 1990 for a terrestrial example, Estes et al. 1998 for a marine example).

\section{Population consequences}

Most experimental studies in marine benthic/demersal communities have emphasized mechanisms and processes, but few have expanded these mechanisms and processes to demonstrate population-level effects. The main reason for this failure is that the research is not conducted for sufficiently long periods or/and over sufficiently large areas. Since species and populations are the essential currency of applied ecology and the grist of evolution. future research is needed to bridge this gap from the qualitative to the quantitative. Furthermore, innovations to our understanding of the generation of population and even community dynamics can come from studies relating individual behavioral or physiological responses to environmental forcing: rarely do such studies make the connections between the individual and the population, despite a potential for enhancing predictive capacity by uncovering the underlying mechanisms for population and community change (Bertness 1992, Wootton 1993, Micheli 1997).

\section{Developing stronger working relationships between scientists and managers}

Several of the challenges identified in this review are not easily addressed solely within the province of basic research. However, researchers working in collaboration with regulatory and management agencies could address some of them. There has been an appeal by many scientists for application of the principles of ecosystem management; yet the protocols for applying this approach to marine ecosystems are undefined (Botsford et al. 1997). An example of the potential utility of merging science and management is the development of marine protected areas for the joint purpose of conserving exploited populations, assessing population-to-ecosystem-level impacts of fisheries, and determining the roles of large predatory fishes in benthic/demersal communities. While fishing is perhaps the most well known agent of anthropogenic influence on marine ecosystems, eutrophication is another process that is dramatically transforming estuarine and shallow coastal systems in some parts of the world (Turner \& Rabalais 1994, Nixon 1995, Paerl et al. 1998). Much research has been devoted to understanding the effects of nutrient loading on phytoplankton (without yet adequate understanding of the dynamics of nuisance blooms). Yet the food-chain consequences of nutrient loading, and how change in productivity and composition of the microalgal assemblage alters the composition, production, interactions and dynamics of consumers at higher trophic levels are unknown (Paerl et al. 1998). The use of environmental management on the scales of watersheds for large-scale experiments, with resource managers working in conjunction with marine ecologists, holds tremendous promise for answering important questions about system dynamics and the sustainability of ecosystem services

\section{Biodiversity}

Biodiversity has emerged as a powerful scientific and social allegory, largely because species and populations are being lost at alarmingly high rates from many terrestrial systems (Soulé \& Sanjayan 1998). The oceans are a paradox in this regard (Roberts \& Hawkins 1999). On the one hand, some of the strongest evidence for changes in biodiversity comes from the fossil record of marine species (Sepkoski et al. 1981), thus demonstrating that the sea is not invulnerable to mass extinction. On the other hand, while presently species are being lost at high rates from some terrestrial systems, few marine species are known to have become extinct during the 20th century (Carlton 1993). Reasons for this apparent discrepancy are intriguing and warrant further evaluation by marine ecologists. Are recent extinctions of marine species in fact rare, or is it simply that the taxonomy of so many of these spe cies remains to be properly described? In addition understanding the role of biodiversity looms as a major challenge. Given the apparent redundancy of species within functional groups in many marine benthic/ demersal systems, what significance does that diver sity have to the dynamics and sustainable functioning of any given system? Answers to these questions are 
important for assessing environmental impacts, designing relevant monitoring programs, and managing the health of marine ecosystems.

Research funding to study marine ecosystems is never sufficient to assess all component species, so the degree to which species can be pooled by taxonomic/functional group without loss of important information about the state and dynamics of the system has critical implications to the conduct of science. Answers to this problem should also help shed light on why some systems seem so readily invaded by exotics, and might help define and protect ecosystem integrity and sustainability - perhaps the greatest challenge of the 21st century (Carlton 1989).

Acknowledgements. An earlier version of this paper was written as a background document for the OEUVRE (Ocean Ecology: Understanding and Vision for Research) workshop, convened by the U.S. National Science Foundation's Division of Ocean Sciences in March 1998 at Keystone, Colorado. We thank M. E. Hay and P. A. Jumars for inviting us to participate in the workshop and for comments on an earlier version of the review. Partial support was provided by NSF Grant OCE 97 12809 (to C.H.P). We appreciate the substantial input from countless numbers of our colleagues at the workshop and afterwards. The paper itself was improved by comments from P. K. Dayton and 2 anonymous referees. S. L. Reese helped prepare for publication.

\section{LITERATURE CITED}

Alcala AC, Russ GR (1990) A direct test for the effects of protective management on abundance and yield of tropical marine resources. J Cons Int Explor Mer 46:40-47

Allen MJ, Smith GB (1988) Atlas and zoogeography of common fishes in the Bering Sea and Northeastern Pacific. NOAA Natl Mar Fish Serv Tech Rep US Dep Commerce $66: 1-148$

Anderson PJ, Piatt JF (1999) Community reorganization in the Gulf of Alaska following ocean climate regime shift. Mar Ecol Prog Ser 189:117-123

Baumgartner TR, Soutar A, Ferreira-Bartrina V (1992) Reconstruction of the history of Pacific sardine and northern anchovy populations over the past two millenia from sediments of the Santa Barbara basin, California. Rep Calif Coop Ocean Fish Invest (CalCOFI) 33:24-41

Bertness MD (1992) The ecology of New England salt marsh plant communities. Am Sci 80:260-268

Blegvad H (1928) Quantitative investigations of bottom invertebrates in the Limfjord 1910-1927 with special reference to the plaice food. Rep Dan Biol Stn 34:33-52

Block BA, Finnerty JR, Stewart AFR, Kidd J (1993) Evolution of endothermy in fish: mapping physiological traits on a molecular phylogeny. Science 260:210-214

Botsford LW, Castilla JC, Peterson CH (1997) The management of fisheries and marine ecosystems. Science 277 : $509-514$

Brown JH (1995) Macroecology. University of Chicago Press, Chicago

Brown JH, Heske EJ (1990) Control of a desert-grassland transition by a keystone rodent guild. Science 250:1705-1707

Butman CA (1987) Larval settlement of soft-sediment inverte- brates: the spatial scales of pattern explained by active habitat selection and the emerging role of hydrodynamical processes. Oceanogr Mar Biol Annu Rev 25:113-165

Caley MJ, Carr MH. Hixon MA, Hughes TP, Jones JP, Menge BA. (1996) Recruitment and the local dynamics of open marine populations. Annu Rev Ecol Syst 27:477-500

Carlton JT (1989) Man's role in changing the face of the ocean: biological invasions and implications for conservation of near-shore environments. Conserv Biol 3:265-273

Carlton JT (1993) Neoextinctions of marine invertebrates. Am Zool 33:499-509

Carpenter SR, Kitchell JF (1993) The trophic cascade in lakes. Cambridge University Press, Cambridge

Commito JA, Ambrose WG Jr (1985) Multiple trophic levels in soft-bottom communities. Mar Ecol Prog Ser 26:289-293

Connell JH (1972) Community interactions on rocky intertidal shores. Annu Rev Ecol Syst 3:169-192

Connell JH (1978) Diversity in tropical rain forests and coral reefs. Science 199:1302-1310

Connell JH (1983) On the prevalence and relative importance of interspecific competition: evidence from field experiments. Am Nat 122:661-696

Connell JH, Hughes TP, Wallace CC (1997) A 30-year study of coral abundance, recruitment, and disturbance at several scales in space and time. Ecol Monogr 67:461-488

Davis RW, Fuiman LA, Williams TM, Collier SO, Hagey WP, Kanatous SB, Kohin S, Horning S (1999) Hunting behavior of a marine mammal beneath the Antarctic fast-ice. Science 283:993-996

Dayton PK (1989) Interdecadal variation in an Antarctic sponge and its predators from oceanographic climate shifts. Science 245:1484-1486

Dayton PK, Oliver JS (1980) An evaluation of experimental analyses of population and community patterns in benthic marine environments. In: Tenore KR, Coull BC (eds) Marine benthic dynamics. University of South Carolina Press, Columbia, p 93-120

Dayton PK, Tegner MJ (1984) The importance of scale in community ecology: a kelp forest example with terrestrial analogs. In: Price PW, Slobodchikoff CN, Gaud WS (eds) A new ecology: novel approaches to interactive systems. Wiley, New York, p 457-481

Dayton PK, Thrush SF, Agardy MT (1995) Environmental effects of marine fishing. Aquat Conserv Mar Freshw Ecosystems 5:205-232

Dayton PK, Tegner MJ, Edwards PB, Riser KL (1999) Temporal and spatial scales of kelp demography: the role of oceanographic climate. Ecol Monogr 69:219-250

Doherty PJ, Williams D (1988) The replenishment of coral reef fish populations. Oceanogr Mar Biol Annu Rev 26: $487-551$

Eckman JE (1983) Hydrodynamic processes affecting benthic recruitment. Limnol Oceanogr 28:241-257

Elmgren R, Ankar S, Marteleur B, Ejdung G (1986) Adult interference with postlarvae in soft sediments: the Pontoporeia-Macoma example. Ecology 67:827-836

Estes JA, Tinker MT, Williams TM, Doak DF (1998) Killer whale predation on sea otters linking oceanic and nearshore ecosystems. Science 282:473-476

Fretwell SD (1987) Food chain dynamics: the central theory of ecology? Oikos 50:291-301

Gaines SD, Roughgarden J (1987) Fish in offshore kelp forests affect recruitment to intertidal barnacle populations. Scince 235:479-481

Genin A, Dayton PK, Lonsdale PF, Spiess FN (1986) Corals on seamount peaks provide evidence of current acceleration over deep-sea topography. Nature 322:59-61 
Genin A, Noble M, Lonsdale PF (1989) Tidal currents and anticyclonic motions on two North Pacific seamounts. Deep-Sea Res (Part A) 36:1803-1815

Gentry RL, Kooyman GL (1986) Fur seals: maternal strategies on land and at sea. Princeton University Press, Princeton

Grassle JF (1986) The ecology of deep-sea hydrothermal vent communities. Adv Mar Biol 23:301-362

Grassle JF (1989) Species diversity in deep-sea communities. Trends Ecol Evol 4:12-15

Gurevitch J, Hedges LV (1999) Statistical issues in ecological meta-analyses. Ecology 80:1142-1149

Hall SJ (1994) Physical disturbance and marine benthic communities: life in unconsolidated sediments. Oceanogr Mar Biol Annu Rev 32:179-240

Hay ME, Fenical W (1988) Marine plant-herbivore interactions: the ecology of chemical defense. Annu Rev Ecol Syst 19:111-145

Hughes TP (1989) Community structure and diversity of coral reefs: the role of history. Ecology 70:275-279

Jackson JBC (1991) Adaptation and diversity of coral reefs BioScience 41:475-482

Jackson JBC (1997) Reefs since Columbus. Coral Reefs 16(Suppl): $23-32$

Jones CG, Lawton JH, Shachak M (1994) Organisms as ecosystem engineers. Oikos 69:373-386

Karlson RH, Cornell HV (1998) Scale-dependent variation in local vs. regional effects on coral species richness. Ecol Monogr 68:259-274

Keating BH, Fryer P, Batiza R, Boehlert GW (1987) Seamounts, islands, and atolls. Geophys Monogr 43:1-405

Kneib RT (1988) Testing for indirect effects of predation in an intertidal soft-bottom community. Ecology 69:1795-1805

Kneib RT, Stiven AE (1982) Benthic invertebrate responses to size and density manipulations of the common mummichog. Fundulus heteroclitis, in an intertidal salt marsh. Ecology 63:1518-1532

Lauck T, Clark CS, Mangel M, Munro GR (1998) Implementing the precautionary principle in fisheries management through marine reserves. Ecol Appl 8:S72-S78

Leichter JJ, Wing SR, Miller SL, Denny MW (1996) Pulsed delivery of subthermocline water to Conch Reef (Florida Keys) by internal tidal bores. Limnol Oceanogr 41: $1490-1501$

Levin SA (1992) The problem of pattern and scale in ecology. Ecology 73:1943-1967

Levinton JS, Lopez GR (1977) A model of renewable food resources and limitation of deposit-feeding benthic populations. Oecologia 31:177-190

Lubchenco J (1978) Plant species diversity in a marine intertidal community: importance of herbivore food preference and algal competitive abilities. Am Nat 112:23-39

Martin PS (1973) The discovery of America. Science 179: 969-974

Menge BA, Barlow EL, Blanchette CA, Navarrete SA, Yamada SB (1994) The keystone species concept: variation in interaction strength in a rocky intertidal habitat. Ecol Monogr 64:249-286

Micheli $F$ (1997) Effects of predator foraging behavior on patterns of prey mortality in marine soft bottoms. Ecol Monogr 67:203-224

Mullineaux LS, Wiebe PH, Baker ET (1995) Larvae of benthic invertebrates in hydrothermal vent plumes over Juan de Fuca Ridge. Mar Biol 122:585-596

Nixon SW (1995) Coastal marine eutrophication: a definition, social causes, and future concerns. Ophelia 41:199-219

Nowell ARM, Jumars PA (1984) Flow environments of aquatic benthos. Annu Rev Ecol Syst 15:303-328
Olafsson EB, Peterson CH, Ambrose WG Jr (1994) Does recruitrnent limitation structure populations and communities of macro-invertebrates in marine soft sediments: the relative significance of pre- and post-settlement processes. Oceanogr Mar Biol Annu Rev 32:65-109

Oliver JS, Slattery PN (1985) Effects of crustacean predators on species composition and population structure of softbodied infauna from McMurdo Sound, Antarctica. Ophelia $24: 155-175$

Paerl HW, Pinckney JL, Fear JM, Peierls BL (1998) Ecosystem responses to internal and watershed organic matter loading: consequences for hypoxia in the eutrophying Neuse River Estuary, North Carolina, USA. Mar Ecol Prog Ser $166: 17-25$

Paine RT (1966) Food web complexity and species diversity. Am Nat 100:65-75

Paine RT (1980) Food webs: linkage, interaction strength and community infrastructure. J Anim Ecol 49:667-685

Paine RT (1994) Marine rocky shores and community ecology: an experimentalist's perspective. Excellence Ecol 4: $1-152$

Palumbi SR (1992) Marine speciation on a small planet. Trends Ecol Evol 7:114-118

Pauly D, Christensen V, Dalsgaard J, Froese R, Torres F Jr (1998) Fishing down marine food webs. Science 279: 860-863

Peterson CH (1979) Predation, competitive exclusion, and diversity in the soft-sediment benthic communities of estuaries and lagoons. In: Livingston RJ (ed) Ecological processes in coastal and marine systems. Plenum Press, New York, p 233-264

Peterson $\mathrm{CH}$ (1991) Intertidal zonation of marine invertebrates in sand and mud. Am Sci 79:236-249

Peterson $\mathrm{CH}$, Black R (1987) Resource depletion by active suspension feeders on tidal flats: influence of local density and tidal elevation. Limnol Oceanogr 32:143-166

Pineda J, Caswell H (1998) Bathymetric species-diversity patterns and boundary constraints on vertical range distribution. Deep-Sea Res (II) 45:83-101

Polis GA, Anderson WB, Holt RD (1997) Toward an integration of landscape and food web ecology: the dynamics of spatially subsidized food webs. Annu Rev Ecol Syst 28: 289-316

Power ME, Tilman D, Estes JA, Menge BA, Bond WJ, Mills LS, Daily G, Castilla JC, Lubchenco J, Paine RT (1996) Challenges in the quest for keystones. Bioscience 46 $609-620$

Powers DA, Allendorf FW, Chen TT (1990) Application of molecular techniques to the study of marine recruitment problems. In: Sherman K, Alexander LM, Gold BD (eds) Large marine ecosystems. Patterns, processes and yields. American Association for the Advancement of Science, Washington, p 104-121

Rafaelli D, Hall SJ (1992) Compartments and predation in an estuarine food web. J Anim Ecol 61:551-560

Raffaeli D, Hawkins S (1996) Intertidal ecology. Chapman \& Hall, London

Rex MA, Stuart CT, Hessler RR, Allen JA, Sanders HL, Wilson GDF (1993) Global-scale latitudinal patterns of species diversity in the deep-sea benthos. Nature 365:636-639

Roberts CM Hawkins JP (1999) Extinction risk in the sea. Trends Ecol Evol 14:241-245

Roughgarden J, Gaines S, Possingham H (1988) Recruitment dynamics in complex life cycles. Science 241:1460-1466

Sale P (1977) Maintenance of high diversity in coral reef fish communities. Am Nat 111:337-359

Schmitt RJ (1987) Indirect interactions between prey: appar- 
ent competition, predator aggregation, and habitat segregation. Ecology 68:1887-1897

Segerstråle SG (1962) Investigations on Baltic populations of the bivalve Macoma balthica (L.). Part II. What are the reasons for the periodic failure of recruitment and the scarcity of Macoma in the deeper waters of the inner Baltic? Commentat Biol Soc Sci Fenn 24:1-26

Sepkoski JJ Jr, Bambach RK, Raup DM, Valentine JW (1981) Phanerozoic marine diversity and the fossil record. Nature 293:435-437

Simenstad CA, Estes JA, Kenyon KW (1978) Aleuts, sea otters, and alternate stable-state communities. Science 200:403-411

Snelgrove PVR, Butman CA (1994) Animal-sediment relationships revisited: cause versus effect. Oceanogr Mar Biol Annu Rev 32:111-178

Soulé ME, Sanjayan MA (1998) Conservation targets: do they help? Science 279:2060-2061

Sousa WP (1979) Experimental investigations of disturbance and ecological succession in a rocky intertidal algal community. Ecol Monogr 49:227-254

Steinberg PD, Estes JA, Winter FC (1995) Evolutionary consequences of food chain length in kelp forest communities. Proc Natl Acad Sci USA 92:8145-8148

Thistle D, Levin L (1998) The effect of experimentally increased near-bottom flow on metazoan meiofauna at a deep-sea site, with comparison data on macrofauna. DeepSea Res (I) 45:625-638

Thorson G (1950) Reproductive and larval ecology of marine bottom invertebrates. Biol Rev 25:1-45

Thrush SF and others (1997a) The sandflat habitat: scaling from experiments to conclusions. J Exp Mar Biol Ecol 216: $1-9$

Thrush SF and others (1997b) Scaling-up from experiments

Editorial responsibility: Kenneth Sherman (Contributing Editor), Narragansett, Rhode Island, USA to complex ecological systems: where to next? J Exp Mar Biol Ecol 216:243-254

Tunnicliffe $V(1991)$ The biology of hydrothermal vents: ecology and evolution. Oceanogr Mar Biol Annu Rev 29 $319-407$

Turner RE, Rabalais NN (1994) Coastal eutrophication near the Mississippi River delta. Nature 368:619-621

Underwood AJ, Denley EJ (1984) Paradigms, explanations, and generalizations in models for the structure of intertidal communities on rocky shores. In: Strong DR, Sinzberloff $D$, Abele LG, Thistle AB (eds) Ecological communities: conceptual issues and the evidence. Princeton University Press, Princeton, p 151-180

Underwood AJ, Fairweather PG (1989) Supply-side ecology and benthic marine assemblages. Trends Ecol Evol 4:16-20

White BN (1987) Oceanic anoxic events and allopatric speciation in the deep sea. Biol Oceanogr 5:243-259

Wildish D, Kristmanson D (1997) Benthic suspension feeders and flow. Cambridge University Press, Cambridge

Wilson WH Jr (1986) The importance of predatory infauna in marine soft-sediment communities. Mar Ecol Prog Ser 32 $35-40$

Witman JD (1987) Subtidal coexistence: storms, grazing, mutualism and the zonation of kelps and mussels. Ecol Monogr $57: 167-187$

Witman JD, Leichter JJ, Genovese SJ, Brooks DA (1993) Pulsed phytoplankton supply to the rocky subtidal zone: influence of internal waves. Proc Natl Acad Sci USA 90: $1686-1690$

Woodin SA (1976) Adult-larval interactions in dense infaunal assemblages: patterns of abundance. J Mar Res 34:25-41

Wootton TJ (1993) Indirect effects and habitat use in an intertidal community: interaction chains and interaction modifications. Am Nat 141:71-89

Submitted: February 10, 1999; Accepted: October 26, 1999 Proofs received from author(s): March 17, 2000 